\title{
Sciendo
}

\section{Channel formation in rivers downstream of water reservoirs}

\author{
Ivan Kirvel ${ }^{1 *}$, Mikhail Kukshinov ${ }^{2}$, Alexander Volchek ${ }^{3}$, Pavel Kirvel ${ }^{4}$ \\ ${ }^{1}$ Pomeranian University in Słupsk, Partyzantow 27, Department of Environmental Analysis, 76-200 Slupsk, Poland, e-mail: ivan.kirvel@ \\ apsl.edu.pl (* corresponding author) \\ ${ }^{2}$ Belarusian State University of Informatics and Radioelectronics, Browki 6, 220013 Minsk, Belarus, e-mail: kukshinov.m@gmail.com \\ ${ }^{3}$ Brest State Technical University, Moskovskaya 267, 224017 Brest, Belarus, e-mail: volchak@tut.by \\ ${ }^{4}$ Belarusian State University of Informatics and Radioelectronics, Browki 6, 220013 Minsk, Belarus, e-mail: pavelkirviel@yandex.by
}

\begin{abstract}
The article concerns the study of the influence of river reservoirs of Belarus on the evolution of river channels in their downstream pools. On the basis of observational data from the Republican Hydrometeorological Center of the Republic of Belarus (RHMC), as well as own field observations a quantitative evaluation of the change of the main channel formation factors, the direction, horizontal and vertical parameters of deformation of the riverbeds below dams has been performed. Changes in the type of channel processes for the regulated parts of rivers have also been assessed. It has been found that the investigated reservoirs accumulate up to $65 \%$ of the sediment transported by the river in a suspended state. Restoration of the water turbidity to values close to the natural regime occurs at a distance of $20 \mathrm{~km}$ downstream from a dam of small reservoirs, and up to $50 \mathrm{~km}$ downstream from a dam in the case of medium-sized reservoirs. The degree of the riverbed deformations downstream from a reservoir is defined by the geological and lithologic structure of the channel bottom deposits. If there are easily washed sand deposits at the bottom, then the dominant process is deep erosion. If sediments are more heterogenic with increased admixture of gravel-pebble material the development of directed deep erosion is reduced. The change of the existing type of channel processes of regulated rivers is due to the imbalance between the main factors of channel formation in the initial period of the operation of new water-engineering systems (5-7 years). The observed changes are typical of rivers with sandy riverbed.
\end{abstract}

Key words: fluvial geomorphology, downward and bank erosion, bed material, channel morphometry

\section{Introduction}

The design of various hydraulic structures on rivers requires taking into account the direction of the channel, its possible adjustments and specific manifestations in different conditions, while the work of transport, bridges, inverted siphons, oil and gas pipelines across the river, water intake operation and so on depend on the nature and intensity of channel deformations. Currently, methods for predicting deformations of the riverbed in the same type of channel processes are welldeveloped (Chalov 1979). At the same time the forecast of possible changes in channel processes dependent on changes in the channel from factors, including those under the influence of hydraulic engineering, remains an actual, still not completely solved problem (Fu et al. 2008; Hupp et al. 2009; Parzonka and Kosierb 2010; Sanford 2007; Schmidt and Wilcock 2008). Forecasting the process dynamics in rivers in downstream pools is complicated by the natural conditions of the area where the reservoirs are created, which is reflected in the char- acter of channel deformation. The most optimal solution to this problem is the creation of regional forecasting techniques, based on the results of comprehensive field observations, as close as possible to the conditions of the future reservoirs. Unfortunately, although these regional generalizations are made for a limited number of regions of the world, they are absent in Belarus. Taking into account the approved program of the development of small hydro power in the coming years, one can say with confidence that the demand for science-based information on channel deformations for regulated parts of rivers will increase. Altogether, this indicates the need for further research in this area and determines their relevance.

\section{Study area and methods}

The impact of reservoirs on the environment is to a great extent determined by their size (area, volume) and by the nature of the river regulation (Avakian 1999). According to the accepted gradation (Shirokov 
Table 1. Characteristics of the experimental reservoirs

\begin{tabular}{|c|c|c|c|c|c|c|c|c|c|}
\hline \multirow{2}{*}{$\begin{array}{l}\text { Reservoir } \\
\text { (River) }\end{array}$} & \multirow{2}{*}{$\begin{array}{l}\text { Type of } \\
\text { regulation }\end{array}$} & \multirow{2}{*}{$\begin{array}{c}\text { Surface } \\
\text { area }\left[\mathrm{km}^{2}\right]\end{array}$} & \multicolumn{2}{|c|}{ Volume $\left[\mathrm{hm}^{3}\right]$} & \multirow{2}{*}{$\begin{array}{l}\text { Max. depth } \\
{[\mathrm{km}]}\end{array}$} & \multirow{2}{*}{$\begin{array}{l}\text { Max. width } \\
{[\mathrm{km}]}\end{array}$} & \multirow{2}{*}{ Length [km] } & \multirow{2}{*}{$\begin{array}{l}\text { Flushing } \\
\text { rate }\left[\mathrm{yr}^{-1}\right]\end{array}$} & \multirow{2}{*}{ Complete } \\
\hline & & & nominal & active & & & & & \\
\hline $\begin{array}{l}\text { Vileyka } \\
\text { (Viliya) }\end{array}$ & $\begin{array}{c}\text { Incomplete } \\
\text { long-term }\end{array}$ & 63.8 & 238.0 & 215.0 & 13.0 & 3.0 & 27.0 & 4.15 & $1975 / 1976$ \\
\hline $\begin{array}{l}\text { Salihorsk } \\
\text { (Sluch) }\end{array}$ & Seasonal & 23.1 & 55.9 & 38.1 & 4.5 & 1.9 & 24.0 & 7.58 & 1967 \\
\hline $\begin{array}{l}\text { Rachuny } \\
\text { (Ashmyanka) }\end{array}$ & Daily & 1.5 & 2.29 & 1.21 & 4.7 & 0.8 & 5.5 & 152 & $1958 / 1959$ \\
\hline
\end{tabular}

and Lopukh 1991), on the territory of Belarus there are three groups of reservoirs that interact differently with the environment: very small (volume less than 0.001 $\mathrm{km}^{3}$, surface area less than $3 \mathrm{~km}^{2}$ ), small (volume $0.01-$ $0.1 \mathrm{~km}^{3}$, surface area $3-25 \mathrm{~km}^{2}$ ) and medium (volume $0.1-0.5 \mathrm{~km}^{3}$, surface area $25-100 \mathrm{~km}^{2}$ ). On this basis, one reservoir from each group has been selected for the research, the Rachuny, Salihorsk and Vileyka reservoirs, respectively (Table 1, Fig. 1).

These reservoirs were chosen due to the number of stationary observations of hydrological characteristics regulated, in both the upper and lower pond, carried out by the Republican Hydrometeorological Center of the Republic of Belarus (RHMC).

The study of channel deformation was based on the hydro morphological analysis of the channel processes, on cartographic and hydrological materials, as well as on the basis of personal field observations, conducted in accordance with the recommendations (Popov and Usachev 1981).

During the research it was required to determine the direction of changes and the parameters of the main channel-forming factors, which include the water regime, the sediment load and features of the geological

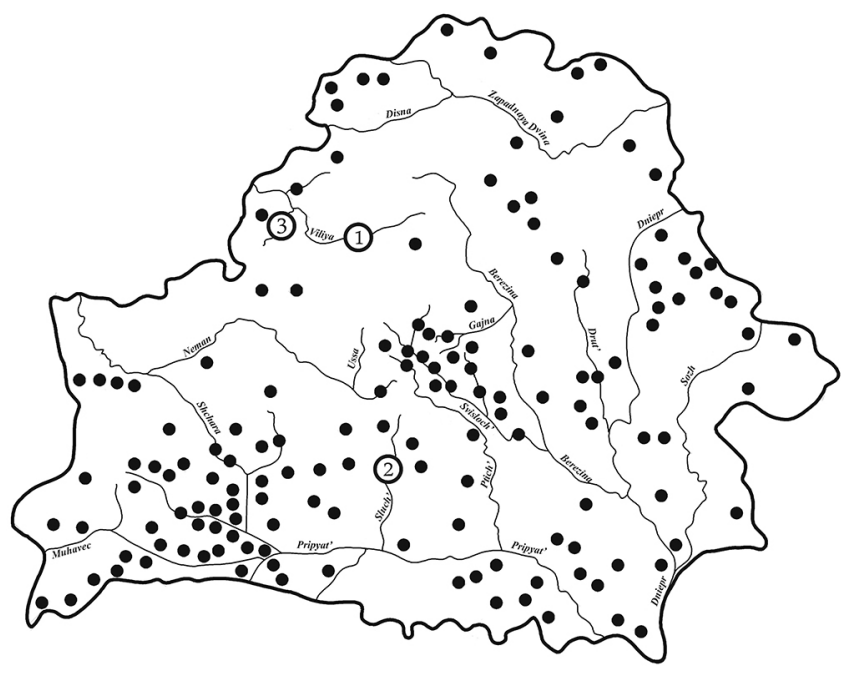

Fig. 1. Distribution of reservoirs on the territory of Belarus. Studied reservoirs are marked with Arabic numerals: 1 - Vileyka; 2 - Salihorsk; 3 - Rachuny structure of the bottom of the river valley. Other factors are of minor importance in the majority of cases and influence the mainstream through its influence on the main factors.

\section{Results and discussion}

\section{Change in the solid runoff under the influence of regulation}

A detailed assessment of changes in the water regime of regulated rivers is presented by Kirvel and Kukshinov (2012). At the same time, artificial reservoirs not only regulate the water flow, but also fundamentally alter the sediment load. The analysis of the source material of the RHMC has shown that there are few observation posts for sediment runoff of the rivers in Belarus, and their ranks are short. Only at the water post of the River Viliya (town Vileyka) were observations of the suspended sediment for the period before (years 1959-1969) and after the creation of the Vileyka Reservoir (years 19832015) made. Under these circumstances, a quantitative evaluation of the changes of the suspended sediment of the River Viliya was obtained after the regulation of its flow, taking into consideration water discharge (Q) and suspended sediment load (SSL) (Fig. 2).

The nature of the existing linkage between monthly averages of SSL and Q is different for periods of high and low water. During the flooding period the interrelationship is non-linear, due to the mismatch between the discrepancy in the time of the water flow change in the river and the sediment discharge.

Using regression equations, which mathematically describe the interrelationship between these two variables, and the monthly average values of water discharge for the period of 1983-2015 the corresponding loads of suspended sediments, which the river should have carried in unchanged natural conditions, were determined. The comparison of the obtained values with the actual data for this period (changed conditions) reflects the degree of the influence of the reservoir on the expenditure of suspended sediments in the river after the regulation of its flow (Table 2).

On the basis of the calculations it has been indicated that the Vileyka Reservoir accumulates about $65 \%$ of 

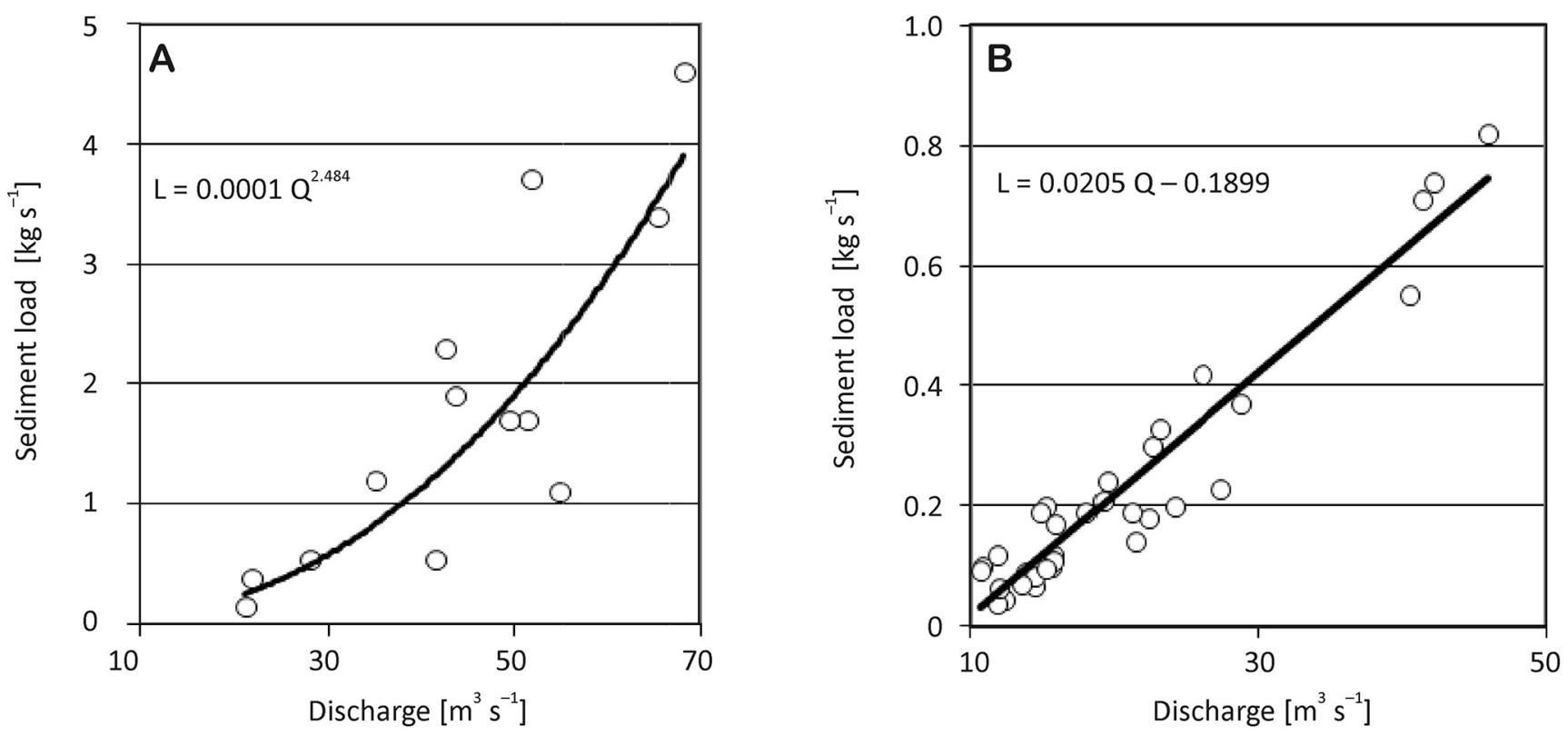

Fig 2. Relationship between the monthly averages of the suspended sediment load (SSL) and water discharge (Q) in River Viliya (town Vileyka) in the years 1959-1962 calculated for the period of high water (March-May) - plate A, and for the period of low water (June-February) - plate B

the average annual sediment load transported by the river in a suspended state and the entire flow drawn by the sediment. The correlation of the discharge and the suspended sediment load is defined by the physical and geographical conditions, as well as by the hydraulic characteristics of the flow. Therefore, in each case, this value will be different. For lowland rivers the sediment runoff is on average 10-15\% of the total sediment load (Karaushev 1977). Within the territory of Belarus the sediment runoff observations, unfortunately, are not kept, which does not permit a more precise quantification of this part of the sediment. One of the reasons for this is the lack of sufficiently reliable instruments and methods of measurement of the drawn sediment. The experimental studies of several authors have shown that the transport of the drawn sediment is distributed unevenly through the flow section of the stream and is pulsating in nature, so that errors can reach $800 \%$ (Pozdniakov and Romanovsky 1983; Sidorchuk 1992). The method for determining sediment yield on the movement of the bottom ridges also has low accuracy on account of the absence of transit deposits.

The maximum sediment retention capacity of the reservoirs in relation to the suspended sediment runoff (more than $80 \%$ ) is set for the period of high water, characterized by the highest turbidity of the water in

Table 2. Effect of the Vileyka Reservoir on the suspended sediment loads in River Viliya downstream of the reservoir (post Vileyka). Calculations were made for the period of 1983-2015

\begin{tabular}{|c|c|c|c|c|c|}
\hline \multirow{2}{*}{ Month } & \multirow{2}{*}{$\begin{array}{c}\text { Regression } \\
\text { equation }\end{array}$} & \multicolumn{2}{|c|}{ Average load $\left[\mathrm{kg} \mathrm{s}^{-1}\right]$} & \multicolumn{2}{|c|}{ Difference } \\
\hline & & Changed conditions & Natural conditions & Absolute $\left[\mathrm{kg} \mathrm{s}^{-1}\right]$ & Relative [\%] \\
\hline January & $R=0.0205 Q-0.19$ & 0.19 & 0.43 & -0.24 & -55.8 \\
\hline February & $R=0.0205 Q-0.19$ & 0.14 & 0.43 & -0.29 & -67.4 \\
\hline March & $\mathrm{R}=0.0001 \mathrm{Q}^{2.484}$ & 0.37 & 1.40 & -1.03 & -73.6 \\
\hline April & $R=0.0001 Q^{2.484}$ & 0.58 & 3.16 & -2.58 & -81.6 \\
\hline May & $\mathrm{R}=0.0001 \mathrm{Q}^{2.484}$ & 0.25 & 0.45 & -0.20 & -44.5 \\
\hline June & $R=0.0205 Q-0.19$ & 0.20 & 0.37 & -0.17 & -45.9 \\
\hline July & $R=0.0205 Q-0.19$ & 0.25 & 0.32 & -0.07 & -21.8 \\
\hline August & $R=0.0205 Q-0.19$ & 0.20 & 0.20 & 0.00 & 0.0 \\
\hline September & $R=0.0205 Q-0.19$ & 0.15 & 0.18 & -0.03 & -16.7 \\
\hline October & $R=0.0205 Q-0.19$ & 0.22 & 0.28 & -0.06 & -21.4 \\
\hline November & $R=0.0205 Q-0.19$ & 0.19 & 0.30 & -0.11 & -36.7 \\
\hline December & $R=0.0205 Q-0.19$ & 0.13 & 0.38 & -0.25 & -65.8 \\
\hline Average year & - & 0.24 & 0.66 & -0.42 & -63.6 \\
\hline
\end{tabular}


Ivan Kirvel et al.

Table 3. Granulometric composition of the suspended sediments upstream (above) and downstream of (below) the studied reservoirs. Values are given as a percentage of total weight

\begin{tabular}{|l|l|c|c|c|c|c|c|c|c|}
\hline \multirow{2}{*}{ Reservoir (date) } & \multirow{2}{*}{ Sampling point } & \multicolumn{7}{|c|}{ Relative weight in grain size classes (diameters in mm) } \\
\cline { 3 - 9 } & & $1-0.5$ & $0.5-0.2$ & $0.2-0.1$ & $0.1-0.05$ & $0.05-0.01$ & $0.01-0.005$ & $0.005-0.001$ & $<0.001$ \\
\hline \multirow{2}{*}{ Vileyka (15 APR 2015) } & above & 2.6 & 7.9 & 17.6 & 19.6 & 23.1 & 11.1 & 11.1 & 7.0 \\
\cline { 2 - 9 } & $350 \mathrm{~m}$ below & - & 0.2 & 9.1 & 22.8 & 24.0 & 15.2 & 16.8 & 11.9 \\
\hline \multirow{2}{*}{ Vileyka (16 AUG 2017) } & above & 0.2 & 4.8 & 8.1 & 20.6 & 21.4 & 18.6 & 16.2 & 10.1 \\
\cline { 2 - 9 } & $350 \mathrm{~m}$ below & - & 0.5 & 3.3 & 20.0 & 24.5 & 21.2 & 19.0 & 11.5 \\
\hline Vileyka (20 OCT 2015) & above & 0.4 & 4.6 & 5.1 & 16.9 & 22.2 & 24.4 & 16.0 & 10.4 \\
\cline { 2 - 9 } & $350 \mathrm{~m}$ below & - & 0.4 & 3.5 & 19.9 & 22.1 & 22.4 & 17.9 & 13.8 \\
\hline Salihorsk (21 AUG 2015) & below & - & 0.5 & 7.6 & 20.5 & 25.3 & 19.3 & 15.8 & 11.0 \\
\hline Rachuny (07 SEP 2015) & below & - & 0.4 & 10.3 & 22.2 & 28.2 & 16.2 & 12.6 & 10.1 \\
\hline
\end{tabular}

the river. This is due, on one hand, to the accumulation of a large reservoir of water flow in the river during the period of high water, and consequently, due to the sediment contained in the volume of water; on the other hand - it is determined by the change in particle size distribution of the suspended sediment during the year. Thus, in the period of high water when the river flow is enhanced by large amounts of water from watersheds and river bed erosion is activated, the particle size distribution of the suspended sediment transported by the river is enlarged. As the result of the overpressure caused by the reservoir, most of the particles fall out of the flow and the downstream receives only the smallest fraction, as proved by the data in Table 3. A similar situation was observed in the ponds of Belarus (Kirvel 2005).

Table 4. Distribution of the turbidity upstream (above) and downstream of (below) the studied reservoirs

\begin{tabular}{|c|c|c|c|}
\hline Reservoir & Date & Sampling point & \begin{tabular}{|c} 
Turbidity \\
{$\left[\mathrm{mg} \mathrm{dm}^{-3}\right]$}
\end{tabular} \\
\hline \multirow[t]{12}{*}{ Vileyka } & \multirow[t]{2}{*}{15 APR 2015} & above the reservoir & 20.2 \\
\hline & & below (at the spillway) & 4.6 \\
\hline & \multirow[t]{4}{*}{25 JUN 2015} & above the reservoir & 11.8 \\
\hline & & below (at the spillway) & 3.9 \\
\hline & & $\begin{array}{l}\text { below (at the distance of } \\
10 \mathrm{~km})\end{array}$ & 10.1 \\
\hline & & $\begin{array}{l}\text { below (at the distance of } \\
50 \mathrm{~km})\end{array}$ & 12.6 \\
\hline & \multirow[t]{2}{*}{02 AUG 2015} & above the reservoir & 11.2 \\
\hline & & below (at the spillway) & 11.3 \\
\hline & \multirow[t]{2}{*}{20 OCT 2015} & above the reservoir & 8.9 \\
\hline & & below (at the spillway) & 5.1 \\
\hline & \multirow[t]{2}{*}{16 AUG 2017} & above the reservoir & 9.9 \\
\hline & & below (at the spillway) & 9.9 \\
\hline \multirow[t]{4}{*}{ Salihorsk } & \multirow[t]{2}{*}{18 JAN 2016} & above the reservoir & 4.7 \\
\hline & & below (at the spillway) & 3.3 \\
\hline & \multirow[t]{2}{*}{20 JUL 2016} & above the reservoir & 6.1 \\
\hline & & below (at the spillway) & 5.7 \\
\hline \multirow[t]{3}{*}{ Rachuny } & \multirow[t]{3}{*}{20 JUN 2014} & above the reservoir & 6.4 \\
\hline & & below (at the spillway) & 5.9 \\
\hline & & $\begin{array}{l}\text { below (at the distance of } \\
20 \mathrm{~km} \text { ) }\end{array}$ & 6.2 \\
\hline
\end{tabular}

As the flow moves downstream the amount of the transported sediments increases until their value corresponds to its conveying capacity. The calculations made according to the formula proposed by Karaushev (1976) have shown that the saturation of the flow with the sediment downstream of the studied reservoirs should be held on a river section the length of which ranges from 1.0 to $1.5 \mathrm{~km}$. At the same time during the field studies it has been revealed that the natural turbidity of water returns to normal only at the distance from about 20 to 50 kilometers below the alignment of the dam (Table 4).

This marked discrepancy is explained by the lack of sediment supply downstream from the overlying land, resulting in the fact that the zone of flow saturation with sediment gradually moves down the river and reaches the values specified in Table 4 . This is confirmed by studies conducted downstream of the large reservoirs of Russia. Thus, according to Makkaveev (1957), in the first years after the establishment of the Rybinsk waterworks the turbidity flow was restored to natural values at a distance of about $2 \mathrm{~km}$, and 6-7 years later at the distance of more than $20 \mathrm{~km}$. Similar changes have been recorded in Bukhtarma, Tsimlyansk, Novosibirsk, Otkaznoye, Włocławek and a number of other reservoirs (Vostriakova et al. 1975; Babiński 2002).

Thus, downstream of the studied reservoirs, along with changes in the water regime of the rivers. a sediment load reduction has been noted as a result of their accumulation in the reservoir. These changes have resulted in a new flow and river bed ratio, causing regular horizontal and vertical deformations of the riverbed downstream of the reservoirs.

\section{Vertical deformation of the river channels downstream of the reservoirs}

The restoration of the natural flow of the turbidity downstream of the dam is accompanied by the significant vertical deformation of the riverbed, which is conventionally divided into local deformation and general transformation. Local deformations are manifested in the form of riverbed erosion at the foreground of the 
Table 5. Morphometric characteristic of the erosion funnels (pools) cuted downstream of the studied reservoirs. Values are given in meters

\begin{tabular}{|l|c|c|c|}
\hline \multicolumn{1}{|c|}{ Reservoir } & Width & Length & $\begin{array}{c}\text { Maximum } \\
\text { depth }\end{array}$ \\
\hline Vileyka & 100 & 120 & 4.8 \\
\hline Salihorsk & 80 & 100 & 4.5 \\
\hline Rachuny & 50 & 60 & 3.0 \\
\hline
\end{tabular}

Table 6. Flow velocity in the channels downstream of the studied reservoirs $\left(\mathrm{m} \mathrm{s}^{-1}\right)$

\begin{tabular}{|l|c|c|c|}
\hline \multirow{2}{*}{ Reservoir (date) } & \multicolumn{3}{|c|}{ Distance from the dam [in meters] } \\
\cline { 2 - 4 } & $5-10$ & $200-250$ & $1600-1800$ \\
\hline Vileyka (01 JUL 2015) & $3.5-4.1$ & $0.65-0.70$ & $0.48-0.55$ \\
\cline { 3 - 4 } & & $0.36-0.40$ & $0.28-0.36$ \\
\hline Salihorsk (04 JUL 2015) & $2.8-3.4$ & $0.46-0.55$ & $0.25-0.28$ \\
\cline { 3 - 4 } & & $0.30-0.36$ & $0.15-0.18$ \\
\hline Rachuny (07 JUL 2015) & \multirow{2}{*}{$2.5-3.3$} & $0.48-0.56$ & \multirow{2}{*}{-} \\
\cline { 3 - 4 } & & $0.31-0.36$ & \\
\hline
\end{tabular}

Note: Numerator presents superficial water flow velocity, and denominator contains near bottom water flow velocity.

dam in the first years of the operation of the reservoirs, thus forming the so called erosion funnels. A survey of riverbed morphology just below dams has revealed significant local bottom deformations (Table 5).

The main cause of the local erosion of a channel is the significant increase in flow velocity and turbulence due to local concentration of the flow kinetic energy and its incomplete quenching. The research results showed that the speed of water flow directly below the spillway of the studied reservoirs reaches $2.5-4.1 \mathrm{~m} \mathrm{~s}^{-1}$.

Gradually, washout of the sediments at this site declines (partially because of the expansion of the channel's capacity) and moves down the river, forming an area of total erosion. Since the increased flow velocities are extinguished mostly in the erosion funnels (as evidenced by the data in Table 6), thus the shaping of the common erosion area occurs mainly due to the lack of sediment supply from the underlying portion of the riverbed.
An integral indicator of the intensity of channel deformations is its general stability, which is defined by the ratio of the channel-shaping sediment size to the flow speed. This condition is related to the mobility of the channel-shaping sediments, and hence the degree of its deformation. Downstream of the studied reservoirs sediments are dominated by medium and coarse sand fractions with some admixture of pebble and gravel (Table 7).

Further down the river there is a general tendency for reducing the sediment size. Thus, the diameter of the sediment fine particles $\left(\mathrm{d}_{10 \%}\right)$ near the dam of the Vileyka Reservoir is $0.35 \mathrm{~mm}$, while at a distance of 50 $\mathrm{km}-0.12 \mathrm{~mm}$ (Fig. 3). The value of the average sediment grain size $\left(\mathrm{d}_{50 \%}\right)$ along the length downstream of the reservoir was also less, from 0.62 to $0.45 \mathrm{~mm}$. Large particle diameter $\left(\mathrm{d}_{90 \%}\right)$ near the dam is close to 1.3 $\mathrm{mm}$, and after $50 \mathrm{~km}$ this falls to $0.7 \mathrm{~mm}$.

Thus, the composition of the sediments below the dam complies with its weight and the flow velocity. The fines are washed away gradually and entrained by the flow, which leads to the sediments coarsening and forms the blind area. However, as Mirckhulava (1967) indicates, formation of such areas is not typical for the sandy sediments, since the entire size range of these sediments has almost the same erosion velocity. As a result, the equilibrium state of the sandy beds is achieved by the reducing the free surface slopes to the maximum stability and by the changing of the shape of the channel cross-section.

Estimation of the direction and size of channel highwater deformations downstream of the reservoirs was carried out by tracing the combined cross-channel side views at gauging stations located downstream of the reservoirs: River Viliya - post Vileyka, River Sluch post Starobin, River Ashmyanka - post Yatsyny. Materials of depth measurements related to the dates of the channel-shaping expenditures have allowed the process of channel erosion to be highlighted over a long-time period.

Table 7. Grading of the sediments upstream and downstream of the studied reservoirs

\begin{tabular}{|c|c|c|c|c|c|c|c|c|c|c|c|}
\hline \multirow{2}{*}{ Reservoir } & \multirow{2}{*}{ Place of sampling } & \multicolumn{9}{|c|}{ Relative weight in grain size classes (diameters in $\mathrm{mm}$ ) } & \multirow{2}{*}{ Soil type } \\
\hline & & $>10$ & $10-5$ & $5-2$ & $2-1$ & $1-0.5$ & $0.5-0.2$ & $0.2-0.1$ & $0.1-0.05$ & $<0.5$ & \\
\hline \multirow[t]{4}{*}{ Vileyka } & above reservoir & - & 0.3 & 2.3 & 5.5 & 13.2 & 52.1 & 18.0 & 6.0 & 2.6 & medium sand \\
\hline & $350 \mathrm{~m}$ below reservoir & 0.8 & 3.6 & 5.3 & 4.7 & 61.9 & 15.8 & 4.5 & 2.4 & 1.0 & coarse sand \\
\hline & $10 \mathrm{~km}$ below reservoir & - & 0.1 & 0.8 & 3.2 & 20.2 & 48.4 & 15.8 & 8.6 & 2.9 & medium sand \\
\hline & $50 \mathrm{~km}$ below reservoir & - & 0.2 & 1.5 & 3.6 & 12.4 & 49.2 & 23.2 & 5.0 & 4.9 & medium sand \\
\hline \multirow[t]{2}{*}{ Salihorsk } & above reservoir & - & - & 0.1 & 2.5 & 12.0 & 53.0 & 21.7 & 7.5 & 3.2 & medium sand \\
\hline & $350 \mathrm{~m}$ below reservoir & - & 1.4 & 4.2 & 6.8 & 31.2 & 36.3 & 9.4 & 8.6 & 2.1 & coarse sand \\
\hline \multirow[t]{3}{*}{ Rachuny } & above reservoir & 0.1 & 2.3 & 3.5 & 9.2 & 13.5 & 56.6 & 12.0 & 1.8 & 1.0 & medium sand \\
\hline & $350 \mathrm{~m}$ below reservoir & 23.6 & 11.2 & 11.6 & 13.3 & 25.3 & 12.2 & 1.3 & 1.0 & 0.5 & semi-gravel sand \\
\hline & $15 \mathrm{~km}$ below reservoir & 8.3 & 10.9 & 12.1 & 14.0 & 23.2 & 14.6 & 5.4 & 7.9 & 3.6 & semi-gravel sand \\
\hline
\end{tabular}

Note: Above the reservoirs river soil samples were collected above the backwater zone of the underlying reservoir. 


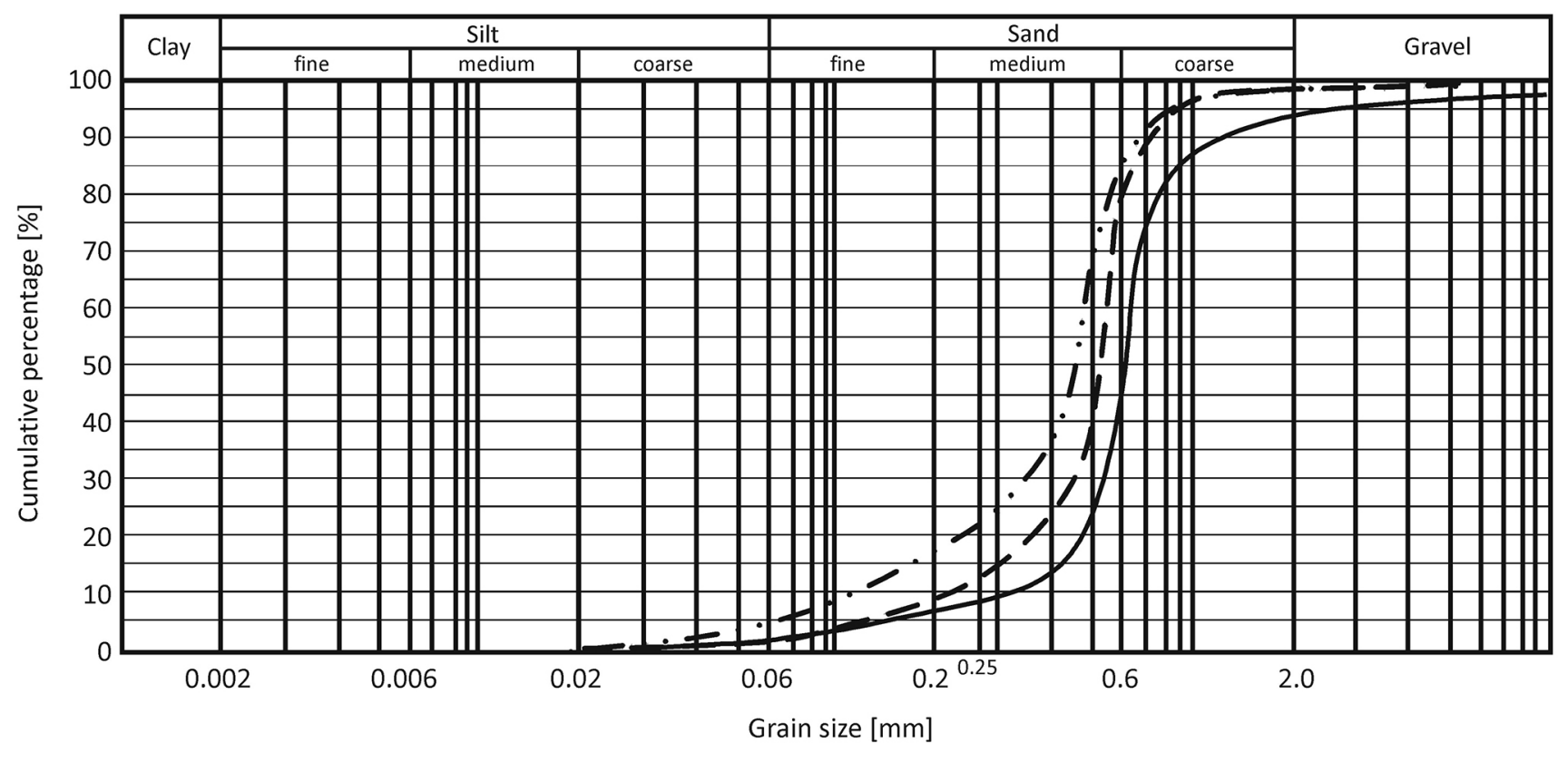

Fig 3. Cumulative curves of grain size distribution in bottom sediments of the River Viliya downstream of the Vileyka Reservoir

Until the regulation of the flow of the River Viliya the vertical deformations of the channel in the area of Vileyka town, located at the distance of 4.2 kilometers below the dam, were significant during the year and reached 1.5 meters. After the creation of the reservoir they substantially reduced, due to the decrease in the amount of channel-forming sediment, completely captured by the reservoir. Slight deformations of the bot-

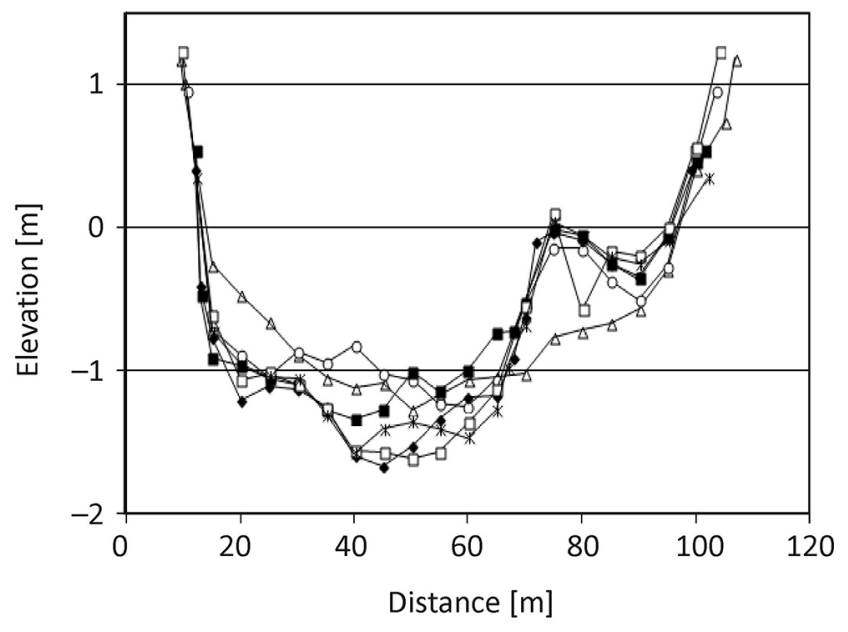

\begin{tabular}{l}
$\longrightarrow$ 18.04.1965 $\rightarrow 02.04 .1979 \rightarrow 14.05 .1985$ \\
$\rightarrow-26.06 .1991 \quad \rightarrow-23.07 .1998 \quad \rightarrow 04.03 .2012$ \\
\hline
\end{tabular}

Fig. 4. Long-term changes in cross-section of the River Viliya at Viliya survey post (according to RHMC data) tom of the channel (up to $30 \mathrm{~cm}$ ) are associated with the ridge-movement of the sediment formed on the section of the river from the dam to the relevant gauging station.

As demonstrated in Figure 4, from 1979 to 1985 there was a slight increase in the elevation of the bottom of the river bed in the area of the water post Vileyka, caused by the displacement of the sediment accumulation zone here, formed during the active reconfiguration of the channel.

In the following years, owing to the gradual removal of the sediment down the river and due to the thrusting of the common areas of erosion here, there was a marked gradual reduction of the absolute elevation of the bottom of the bed in the area of the post. Over the years 1991-2012 the depth of the channel did not change, which indicates the relative stabilization of the deep erosion, which set in 16 years after the commissioning of the Vileyka Reservoir. The study allowed the speed of the displacement of the total area of erosion downstream of the Vileyka Reservoir to be estimated, which (taking into account the distance travelled 4.2 $\mathrm{km}$, and the time spent on this - 16 years) was about 250 meters per year. At the same time, the front area of the general erosion moves at the speed of about 420 meters per year. This is significantly lower than downstream of the larger reservoirs of Russia. Thus, the displacement rate of the the deep erosion zone below the Gorky water-engineering system was $6-7 \mathrm{~km} \mathrm{yr}^{-1}$, below the Rybinsk water-engineering system - $15 \mathrm{~km}$ 


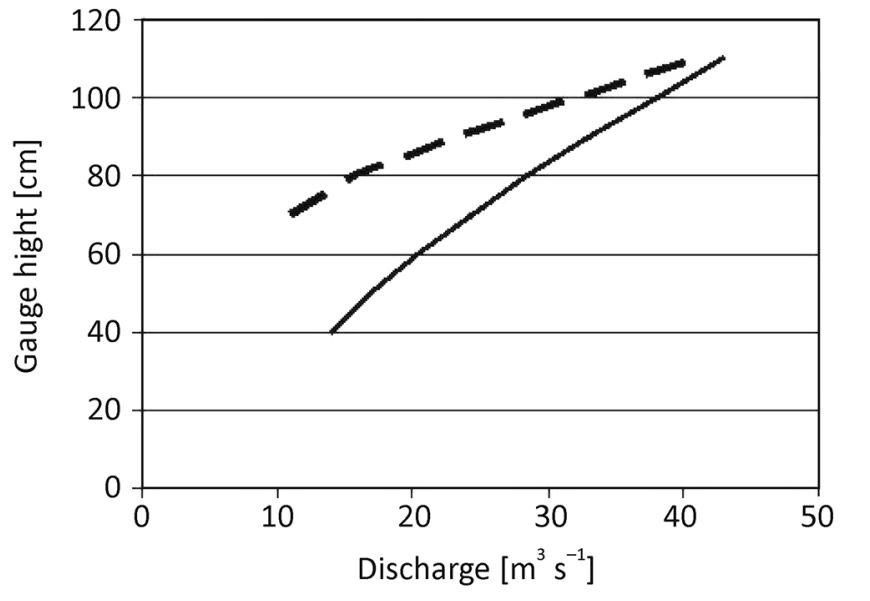

- 1967

2012

Fig 5. Rating curves of River Viliya at Vileyka post over the periods before (dotted line) and after (solid line) the creation of the Vileyka Reservoir

$\mathrm{yr}^{-1}$, and below the Tsimlyansk water-engineering system - 10-12 $\mathrm{km} \mathrm{yr}^{-1}$ (Berkovich 2003). The speed of the erosion front below the Wloclawek dam is on average approximately $1.1 \mathrm{~km}$ per year (Babinski 2002). This difference in the overall movement speed of the common area of erosion can be explained by local hydraulic conditions of the flow, as well as by the size of the sediment distribution. At the same time, it is not possible to discuss the final formation of the riverbed downstream of the Vileyka Reservoir because, accord- ing to Makkaveev's and Chalov's data, the final formation of the longitudinal profile in the plain rivers will only appear 80-100 years after the commissioning of the reservoir (Makkaveev 1957; Chalov 1979). At the same time the final stage of the interaction between the stream and the bed is the form in which the flow erosive energy and the resistance of the soil particles to the erosion are balanced.

To determine the absolute value of the erosion of the channel bottom the method of comparing the rating curves for the periods before and after the creation of the reservoir was applied (Fig. 5). The graph shows a downward trend in the water level of the River Viliya after the regulation of its flow by the reservoir due to the erosion of the riverbed. The decrease of the bottom elevation of the river at the maximum depth over a long period is estimated at 0.4 meters.

Downstream of the Salhorsk Reservoir the previously discussed changes in the main factors of channel formation have not significantly affected the nature of the vertical deformations of the channel below the erosion zone. Apparently, here the natural low turbidity of the River Sluch plays an important role (up to 25

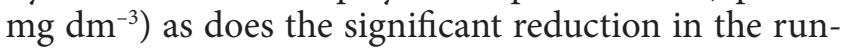
off due to its selection by the Belarusian potash plant for its production needs, alhough it is necessary to note that downstream of the Salihorsk Reservoir dredging and the straightening of the channel bottom has been carried out which could have affected the nature of the channel deformations. It is not possible to estimate this

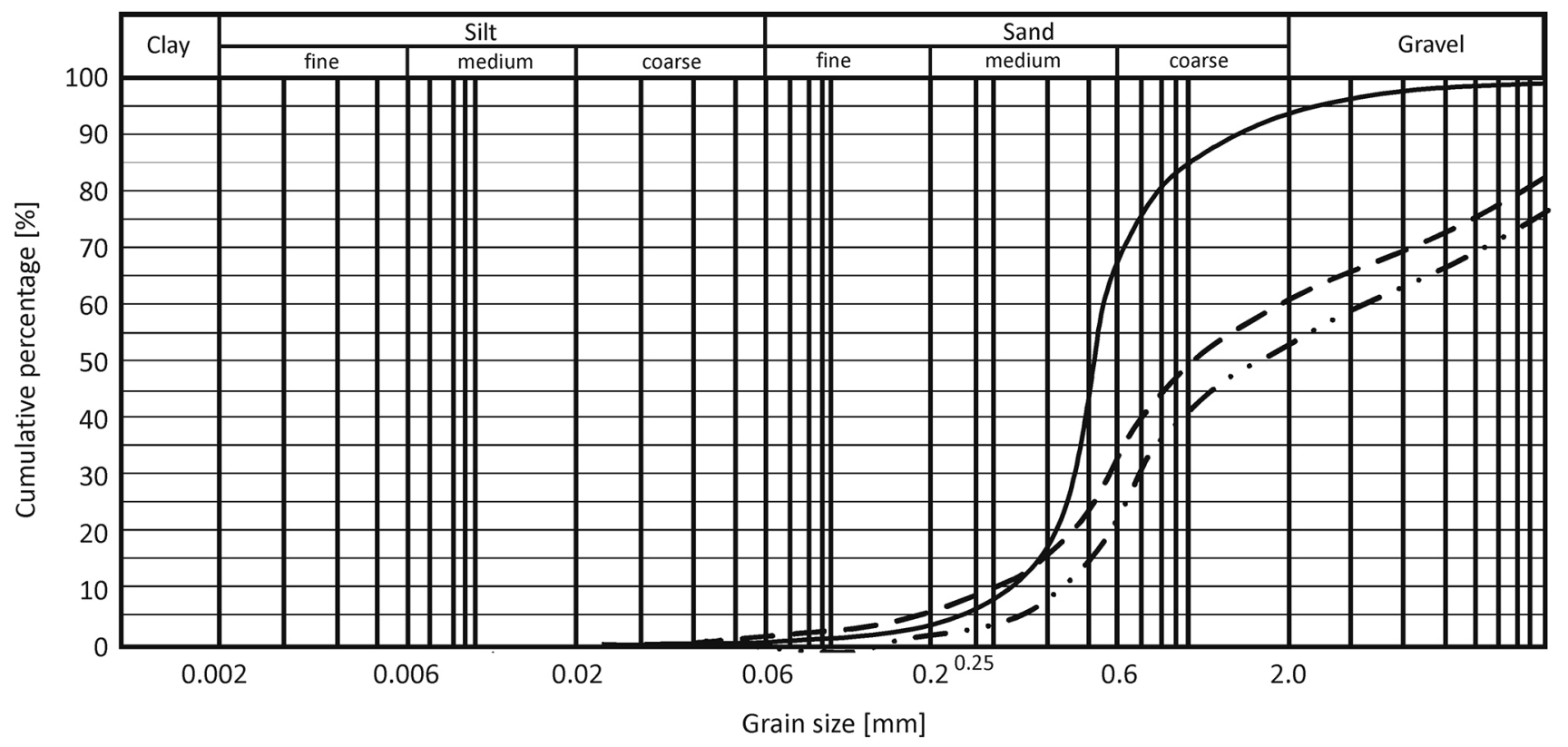

- above reservoir $\quad-\quad-15 \mathrm{~km}$ below dam $\quad \cdots-0.35 \mathrm{~km}$ below dam

Fig. 6. Cumulative curves of grain size distribution in bottom sediments of the River Ashmyanka above and downstream of the Rachuny Reservoir 
due to a lack of relevant observations. On the section of the river below the dam of the Salihorsk Reservoir (as well as downstream of the Vileyka Reservoir) the sorting of the sediment has been noted. Thus, the diameter of the large particles $d_{90} \%$ above the reservoir is $0.65 \mathrm{~mm}$ which increases up to $1.2 \mathrm{~mm}$ below the reservoir. The value of medium size sediments $\left(\mathrm{d}_{50 \%}\right)$ is increases from $0.4 \mathrm{~mm}$ - upstream, up to $0.45 \mathrm{~mm}$ - downstream. The diameters of the small fraction fine particles $\left(\mathrm{d}_{10 \%}\right)$ above and below the reservoir are approximately equal, about $0.1 \mathrm{~mm}$.

The downstream part of the Rachuny Reservoir is characterized by the formation at the bottom of the blind area of coarse gravel-pebble material, which contributes to its stability even in a sharp reduction of sediment load. Thus, upstream of the reservoir the diameter of the small fraction fine particles $\left(\mathrm{d}_{10 \%}\right)$ is $0.35 \mathrm{~mm}$, while below the dam $0.45 \mathrm{~mm}$. The value of the medium coarse sediment $\left(\mathrm{d}_{50 \%}\right)$ increases from $0.51 \mathrm{~mm}$ - above the reservoir, to $1.0 \mathrm{~mm}$ downstream. The diameter of the large particles $\left(\mathrm{d}_{90 \%}\right)$ above the reservoir is $1.55 \mathrm{~mm}$, while below the dam it exceeds $10.0 \mathrm{~mm}$ (Fig. 6).

A reconnaissance survey downstream of the Rachuny Reservoir has shown that the River Ashmyanka along its whole length right up to the mouth has reached the basal horizon - the layer of large deposits, limiting the deep washouts. For these reasons the active deep erosion downstream of the reservoir is not typical. Much of the river bank is hard rock, which the river washed away in an earlier historical period. As a result there are no planar deformations. In places, where the river banks are folded by the easily eroded alluvial deposits, there is a planar deformation of the channel. Displacement of the concave edge of the shore by Giri village ( $15 \mathrm{~km}$ below the dam) over the period of high water of the year 2004 (average water year) was 2.5 meters, at the same time there was practically no change in the value of the bottom level. Thus, the development of the directed vertical deformations of the river channels downstream of the reservoirs will be qualitatively different depending on whether this process is accompanied by the formation of the blind area or not.

\section{Planar deformations of the riverbeds downstream of the reservoirs}

To estimate the planar deformations of the riverbeds below the dam of the reservoir the authors have restored the observation network over the channel processes of the River Viliya, which was established by the RHMC in 1978. The river section of detailed observations, the length of which is $920 \mathrm{~m}$, was situated downstream of the Vileyka Reservoir at the distance of $1.85 \mathrm{~km}$ from the dam and embraces a developed river bend (Table 8).
Table 8. Characteristics of the river bend at the section of detailed observations of channel processes (River Viliya example)

\begin{tabular}{|l|c|c|c|}
\hline \multicolumn{1}{|c|}{ Characteristics } & Year 1978 & Year 2000 & Year 2015 \\
\hline Displacement [m] & 375 & 330 & 329 \\
\hline Length of the bend [m] & 530 & 610 & 612 \\
\hline Sinuosity index & 1.41 & 1.84 & 1.86 \\
\hline Inlet angle [degrees] & 38 & 52 & 52 \\
\hline Outlet angle [degrees] & 92 & 126 & 127 \\
\hline Angle of turn [degrees] & 130 & 178 & 179 \\
\hline
\end{tabular}

Until the regulation of the flow of the River Vilia the area of the detailed observations had been developing by the type of free meandering. The planar deformations of the channel were significant and reached 1.5-3.0 meters annually. The comparison of the channel position as of 1979 with its current position has made it possible to estimate the size and the nature of the planar deformations and the type of change of the channel processes of the River Viliya over the 37-year period of exploitation of the water-engineering system. The fieldwork was conducted along 6 transects using diameters, fixed on the ground with benchmarks (Table 9).

The analysis of the results of the work performed has shown that the maximum channel deformations are typical for the concave banks and on average, for a period after regulation, are about 1 meter per year. Generally, in the area of the observation the amount of erosion is more than the amount of alluvium, which is the result of the river bed transformation due to the changing hydraulic conditions (Table 10).

At the present time planar deformations are poorly retraced even over the period of five years (Table 11). It has been noted that the erosion of the concave bank is observed only in the period of water release from the reservoir, when the flow speed reaches $1.7-1.9 \mathrm{~m} \mathrm{~s}^{-1}$.

Table 9. Planar deformations of the River Viliya channel (in meters) over the period 1978-2015

\begin{tabular}{|c|c|c|}
\hline Transect & Left bank & Right bank \\
\hline 1 & +38.3 & -36.5 \\
\hline 2 & +49.7 & -46.5 \\
\hline 3 & -37.8 & +3.7 \\
\hline 4 & -46.0 & +54.0 \\
\hline 5 & +3.7 & +7.2 \\
\hline 6 & +34.0 & -23.2 \\
\hline
\end{tabular}

Note: sign «+» stands for deposition, and sign «-» stands erosion of sediments.

Table 10. Deposition versus erosion zone in the area of detailed long-term observations (1978-2015) of the River Viliya channel deformation

\begin{tabular}{|c|c|c|c|}
\hline \multicolumn{2}{|c|}{ Deposition zone } & \multicolumn{2}{c|}{ Erosion zone } \\
\hline Area $\left[\mathrm{m}^{2}\right]$ & Volume $\left[\mathrm{m}^{3}\right]$ & Area $\left[\mathrm{m}^{2}\right]$ & Volume $\left[\mathrm{m}^{3}\right]$ \\
\hline 35.000 & 45.500 & 38.000 & 49.400 \\
\hline
\end{tabular}


Table 11. Planar deformations of the River Viliya channel (in meters) over the period 2010-2015

\begin{tabular}{|c|c|c|}
\hline Transect & Left bank & Right bank \\
\hline 1 & +0.5 & -0.4 \\
\hline 2 & +1.0 & -1.0 \\
\hline 3 & -0.2 & +0.1 \\
\hline 4 & -3.5 & +3.0 \\
\hline 5 & +0.6 & -0.4 \\
\hline 6 & +1.8 & -1.3 \\
\hline
\end{tabular}

Note: sign «+» stands for deposition, and sign «-» stands erosion of sediments.

The rate of the flow during the period of mean water, as a rule, doesn't exceed $0.25-0.35 \mathrm{~m} \mathrm{~s}^{-1}$, which contributes to the channel stability during the period.

Thus, regulation of the planar deformations of the River Viliya channel have significantly fallen. The main reason is the decline of the average annual river flow by more than $30 \%$ (as the result of the inter-basin transfer) and its alignment within a year.

At the beginning of the reservoir exploitation (the first 5-7 years) the River Viliya within an area of about $10 \mathrm{~km}$ long below the dam replaced the existing type of channel processes by a mix of free meandering and the braided river (Fig. 7). The superposition of the two types of channel process led to the submission, "conservation" of one of them (in this case of the free meandering) and to the preferential development of another subtype of the riverbed with many branches. The identified changes are caused by the overloading stream sediment, formed as a result of the uncompensated erosion of the riverbed right below the dam. The additional inflow of the sediment is associated with the construction work on the dam, the preparation of the bed and so on. Most of the sediment, going beyond the high flow rates, some distance from the dam settles to the bottom. Similar phenomena are also observed on rivers with an unregulated regime, in violation of the erosion and accumulation processes in the catchment area (Berkovich 2012). Usually such processes are irreversible in natural conditions, and the river cannot go back to the old types of channel process, which is caused by global, secular changes in the main factors affecting channel formation. In the case of the violation of the channelforming factors caused by human intervention, in this case, under the influence of hydraulic engineering, this rule is violated. The gradual stopping of the sediment supply from the erosion craters resulted in a change of the types' subordination: abandonment of the braided river and the «revival» of free meandering. At present the River Viliya continues to evolve according to the type of free meandering, which results in the gradual development of the bend (Table 8).

According to a number of authors, the most typical pattern of freely meandering rivers downstream of reservoirs is the straightening of the river beds and increased bank erosion compared with the natural mode

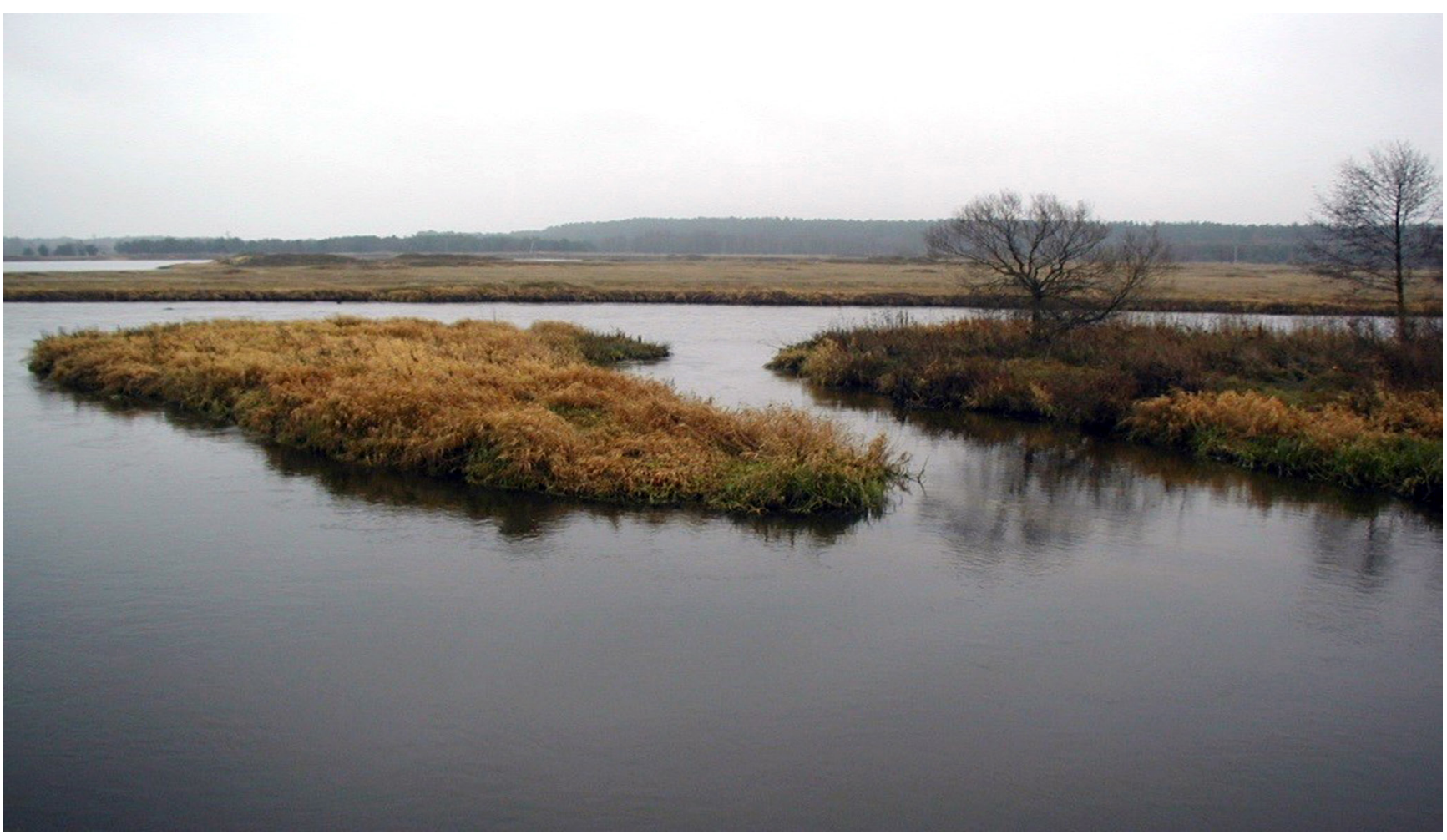

Fig. 7. Braided channel of the River Viliya 
(Kozhevnikov 2002; Turykin 2010). Our research has shown that downstream of the reservoir Vilejskoe there is a slightly different pattern of development of the channel. All this suggests the necessity for regional forecasting techniques and the incorporation of specific conditions for the establishment of future reservoirs.

\section{Conclusions}

1. Reservoirs accumulate up to $65 \%$ of the sediment transported by the river in a suspended state and the entire flow of the drawn by sediment. The maximum sediment retention capacity of reservoirs (reaches $80 \%)$ is typical of the flood period. On the one hand, it is a result of the accumulation of the river flow water in the reservoir during flood, and, consequently the sediment contained in the volume of water; on the other hand, the enlargement of the particle size distribution of the suspended sediment in this period. Restoration of the turbidity flow to values close to the natural regime occurs at a distance of $20 \mathrm{~km}$ downstream of small reservoirs, up to $50 \mathrm{~km}$ downstream of the dam in medium-sized reservoirs.

2. The degree of the vertical deformation of riverbeds downstream of the dam of the reservoir is defined by the geological and lithologic structure of the channel bottom soils. Downstream of the Vileyka Reservoir, if the bottom is easily eroded by the sand deposits, the dominant process is deep erosion. Over the 30year period of the operation of the reservoir the lowering of the riverbed bottom in the common area of erosion with respect to the maximum elevation has reached $40 \mathrm{~cm}$. The velocity of the zone of transgressive erosion downstream of the dam was about 250 meters per year. If there are soils increased with the inclusion of heterogeneity of gravel-pebble material downstream (as in the bottom of the Rachuny Reservoir) the formation of the very blind area is observed, which hinders the development of the directed deep erosion.

3. The change in the type of channel processes of rivers below the dam of reservoirs takes place as a result of changes in the ratio between the main factors forming the channel when these changes go beyond the natural variation of these factors under the existing type of channel processes. Formation of a river bed with many branches in the area of the River Viliya, developing the type of free meandering, is a consequence of the overload of sediment flow, formed as a result of the uncompensated erosion of the riverbed immediately below the apron. This process is reversible, for as a result of the adaptation of the channel to the new hydraulic conditions, the river returns to the original type of the channel processes.

\section{References}

Avakian A.B.,1999, Vodohranilishcha i okruzhayushchaya sreda, [in:] Khublarian M.G. (ed.), Vodnye problemy na rubezhe vekov (Water problems on the eve of new century), Izd. Nauka, Moscow, 217-226 (in Russian).

Babiński Z., 2002, Wpływ zapór na procesy korytowe rzek aluwialnych ze szczególnym uwzględnieniem stopnia wodnego "Wloclawek" (Infuence of dams on the fluvial processes in alluvial rivers with particular reference to the Wlocławek Reservoir), Wydaw. Akad. Bydgoskiej, Bydgoszcz, 185 pp (in Polish).

Berkovich K.M., 2003, Ob izmeneniiakh tipa rusla pri antropogennom vozdeistvii (On changes in the riverbed type under anthropogenic influence), [in:] Chalov R.S., Baryshnikov G.Ya. (eds) Erozionnye i ruslovye processy v Sibiri (Erosion and channel processes in Siberia), Izd. ASU, Barnaul: 66-71 (in Russian).

Berkovich K.M., 2012, Ruslovye processy na rekah v sfere vliianiia vodohranilishch (Riverbed processes in rivers influenced by reservoirs), Izd. MGU, Moscow, 163 pp (in Russian).

Chalov R.S., 1979, Geograficheskie issledovaniia ruslovykh processov (Geographical studies of the channel processes), Izd. MGU, Moscow, 232 pp (in Russian).

Fu K.D., He D.M., Lu X.X., 2008, Sedimentation in the Manwan reservoir in the Upper Mekong and its downstream impacts, Quatern. Int. 186(1): 91-99.

Hupp C.R., Schenk E.R., Richter J.M., Peet R.K., Townsend P.A., 2009, Bank erosion along the dam-regulated lower Roanoke River, North Carolina, [in:] James L.A., Rathburn S.L., Whittecar G.R. (eds), Management and restoration of fluvial systems with broad historical changes and human impacts: Geological Society of America Special Paper 451: 97-108.

Kozhevnikov V.S., 2002, O probleme obshchego razmyva rusel rek v nizhnikh befakh gidrouzlov (On the problem of the common erosion of riverbeds downstream of dams), Trudy GGI 361: 135-145 (in Russian).

Karaushev A.V., 1976, Teoriia i metody rascheta rechnykh nanosov (Theory and methods of calculation of river sediments), Gidrometeoizdat, Leningrad, 272 pp (in Russian).

Karaushev A.V. (ed.), 1977, Stok nanosov, ego izuchenie i geograficheskoe raspredelenie (Sediment runoff, its study and geographic distribution), Gidrometeoizdat, Leningrad, 240 pp (in Russian).

Kirvel I.I., 2005, Prudy Belarusi kak antropogennye vodnye obekty, ikh osobennosti i rezhim (Ponds of Belarus as anthropogenic water bodies, their features and regime), Izd. BGPU, Minsk, 234 pp (in Russian).

Kirvel I.I., Kukshinov M.S., 2012, Vodohranilishcha: za i protiv (Water reservoirs: for and against), Prirod. Res. 1: 69-82 (in Russian).

Makkaveev N.I., 1957, Ruslovye processy i putevye raboty v nizhnikh b'efakh gidrouzlov (Riverbed processes and nav- 
igational works downstream of dams), Trudy CNIIEVT 12: 5-86 (in Russian).

Mirckhulava C.E., 1967, Razmyv rusel i metodika ocenki ikh ustoichivosti (Erosion of channels and methods of their stability), Izd. Kolos, Moscow, 177 pp (in Russian).

Parzonka W., Kosierb R., 2010, Assessment of riverbed erosion process of middle Odra River on Malczyce-Ścinawa section, Stud. Geotech. Mech. 32(1): 131-146.

Popov I.V., Usachev V.F. (eds), 1981, Metodicheskie rekomendatsii UGKS po setevym ruslovym nabliudeniiam (Methodical recommendations of the UGKS on network channel observations), Gidrometeoizdat, Leningrad, 112 pp (in Russian).

Pozdniakov Sh.R., Romanovsky V.V., 1983, Metody izmereniia transporta vlekomykh nanosov (Methods for measuring of bed sediments transport), Trudy GGI 297: 55-62 (in Russian).

Sanford J.P., 2007, Dam regulation effects on sand bar migration on the Missouri River: Southeastern South Dakota [Thesis], University of Montana, Missoula, 85 pp.
Schmidt J.C., Wilcock P.R., 2008, Metrics for assessing the downstream effects of dams, Water Resour. Res. 44(W04404): 1-19.

Shirokov V.M., Lopukh P.S., 1991, Vodohranilishcha Belarussii: prirodnye osobennosti i vzaimodeistvie s okruzhaiushchei sredoi (Reservoirs of Belarus: natural features and interaction with the environment), Izd. Universitetskoe, Minsk, 207 pp (in Russian).

Sidorchuk A.Yu., 1992, Struktura rel'efa rechnogo rusla (Relief structure of riverbed), Gidrometeoizdat, Sankt-Petersburg, 124 pp (in Russian).

Turykin L.A.,2010, Osobennosti deformacij perekatov v nizhnih befah gidrouzlov na ravninnyh rekach (Specific features of whitewater deformations below dams in some lowland rivers), [in:] Nazarov N.N., Berkovich K.M. (eds), Vliianie vodohranilishch na ruslovye process (Influence of reservoirs on riverbed processes), Izd. PSU, Perm: 75-83 (in Russian).

Vostriakova N.V., Lysenko V.V., Shirokov V.M., 1975, Preobrazovanie tverdogo stoka $\mathrm{v}$ srednem techenii $\mathrm{r}$. Obi (Transformation of sediment flow in the middle course of the Ob River), Trudy Sib. NIIE 27: 3-20 (in Russian). 